GEOLOGICAL SURVEY CIRCULAR 555

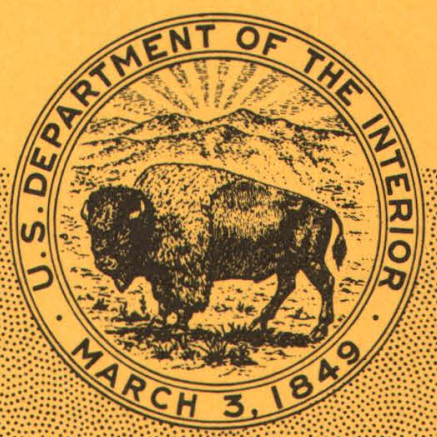

\title{
Bedded Barite in East Northumberland Canyon, Nye County, Nevada
}




\section{Bedded Barite in East}

Northumberland Canyon,

Nye County, Nevada

By D. R. Shawe, F. G. Poole, and D. A. Brobst

GEOLOGICAL SURVEY CIRCULAR 555

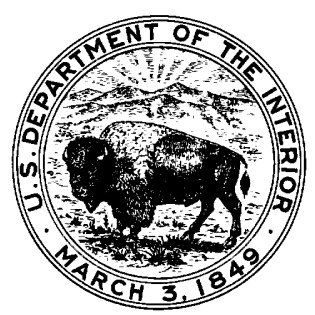


United States Department of the Interior STEWART L. UDALL, Secretary

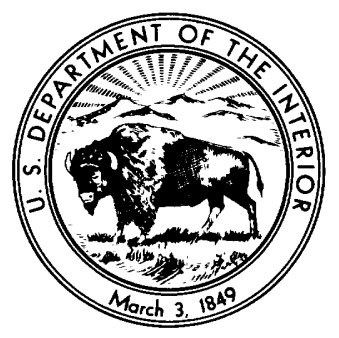

\section{Geological Survey}

William T. Pecora, Director

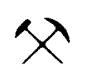

First and second printings 1967

Free on application to the U.S. Geological Survey, Washington, D.C. 20242 


\title{
Bedded Barite in East Northumberland Canyon, Nye County, Nevada
}

\author{
By D. R. Shawe, F. G. Poole, and D. A. Brobst
}

\section{ABSTRACT}

Bedded barite has been identified in the course of stratigraphic studies by the U.S. Geological Survey in and near East Northumberland $\mathrm{C}$ any on, Toquima Range, Nye County, Nev. The barite beds are interlayered in black chert of probable Ordovician age. The barite rock is mostly dark gray and massive, has a specific gravity averaging about 4.0 , and contains, by chemical analysis, 70.7 to 93.9 percent $\mathrm{BaSO}_{4}$.

\section{INTRODUCTION}

Bedded barite has been identified by the U.S. Geological Survey in a new locality near East Northumberland Canyon, Toquima Range, Nye County, Nev. The locality is in a barite province or belt extending generally northward through central Nevada (fig. 1). The province is characterized both by bedded barite associated with rocks of Ordovician and Devonian age and by vein barite associated with Tertiary igneous rocks. Data on many deposits in the province have been given by Horton (1963).

The barite of the East Northumberland Canyon area is interlayered with dark chert of probable Ordovician age. It was identified by the first two authors of this report in June 1967 in the course of a regional study of stratigraphy and structure in south-central Nevada. The stratigraphic studies, an element of the U.S. Geological Survey's Heavy-Metals program, are aimed at clarifying facies distribution of Paleozoic rocks and their relations to the regional structural features which have localized metallic mineral belts in Nevada.

\section{STRATIGRAPHY OF THE BARITE-BEARING BEDS}

The barite beds occur in strata described and mapped by Kay and Crawford (1964, p. 436 and p1. 6) as undifferentiated Willow Canyon Formation and Pinecone Formation of Ordovician age (Kay and Crawford, 1964). These rocks contain faunules equivalent in age to Chazyan, Bolarian, and Trentonian. According to Kay and Crawford (1964, p. 436), the Pinecone Formation consists of grayish-black argillitic siltstone and grayish-black chert with lesser amounts of calcareous siltstone, siliceous siltstone, sandstone, and conglomerate. We believe that rocks shown in the area of the barite beds in figure 2 are mostly Pinecone Formation. The sequence of rocks that includes the barite beds contains much dark-gray to black chert in thin, wavy and lensoid beds 1 and 3 inches thick.

The barite occurs in three principal beds of varying thickness conformably interlayered with thin-bedded dark-gray chert. The barite beds range from 5 to 30 feet in thickness, and one bed locally exceeds 50 feet. In the barite-bearing zone, chert beds total 50 to 200 feet in thickness. Locally there are four barite beds but in some places only one to two beds. Inasmuch as several high-and low-angle faults of small displacement were recognized on the south side of East Northumberland Canyon, and minor tight folds of a few feet amplitude on the north side of the canyon, the variations in thickness and the discontinuity of beds may be attributed more to minor tectonic deformation rather than to original irregularities in deposition.

\section{CHARACTER OF THE BARITE BEDS}

The barite is medium to dark gray and mostly massive and dense and has an aphanitic to extremely fine grained sugary texture. Some of the barite beds have thin laminations one-sixteenth of an inch or more thick. Other layers are well bedded: some of these beds are 1 to 6 inches thick and conta in dark-gray to black rosettes of barite $1 / 10$ to $1 / 2$ inch in diameter. Rare beds have the appearance of intraformational conglomerate and are made up of barite granules and small pebbles, barite rosettes, and sparse chert pebbles of probable detrital origin in an extremely fine grained barite matrix. We saw no chert or argillite layers within the barite beds. The barite beds generally consist of more than 50 percent massive barite and a lesser amount of thin layers of small spherulitic rosettes of barite. The top and bottom of each bed is marked by layers several inches thick of barite rosettes $1 / 4$ to $1 / 2$ inch in diameter.

A diagrammatic stratigraphic section of the baritebearing interval measured on the south side of East Northumberland Canyon, showing sample localities, is illustrated in figure 3 .

\section{PROP ERTIES OF THE BARITE ROCK}

The three types of bedded barite rock (massive bar ite, rosette barite, and conglomeratic barite) are distinctive as seen in thin sections, yet they have similarities. Massive and rosette barite intergrade, pos- 
sibly through an intermediate variety that appears in outcrop as laminated massive barite. Massive barite consists of a dense matted aggregate of feathery to finely bladed barite crystals and $\mathrm{minute}$ barite rosettes a few microns to $0.1 \mathrm{~mm}$ in size, containing a small amount of interstitial streaks and patches of dark opaque organic material. In some thin sections, faint laminations due to grading are evident. Rosette barite consists of less densely packed barite rosettes and some sheafs of barite crystals $0.1 \mathrm{~mm}$ to $1 \mathrm{~cm}$ in diameter in a groundmass of extremely fine grained barite and several percent of interstitial patches and streaks of dark opaque organic material and clear silica. Rosettes are crudely sorted by size in different layers. Conglomeratic barite rock in thin section is similar in appearance to rosette barite, but it is coarser grained and contains rounded to angular fragments of barite, chert, and organic-rich material. Delicately ornamented spherical R adiolaria about $0.1 \mathrm{~mm}$ in diameter occur rather commonly, but not in great abundance, both in the organic matter and in the barite. The Radiolaria generally are cores of barite rosettes.

A few thin veinlets of barite no more than $1 \mathrm{~mm}$ thick, and sparser veinlets of silica of similar size, occur irregularly in all three types of barite rock.

White to light-gray barite collected from old prospect pits about 5 miles northwest of the East Northumberland Canyon deposits appear granular in thin section, with few barite sheafs and no rosettes or organic material. This barite is traceable into darkgray barite interlayered with dark-gray thin-bedded chert in the Pinecone and Willow Canyon Formations undifferentiated (Kay and Crawford, 1964, pl. 6). We believe the light-colored barite was originally bedded barite and is recrystallized as a result of the intrusion of a nearby granitoid stock.

Some physical and chemical properties of 19 samples of barite and a ssociated rocks from the Northumberland Canyon area are summarized in the table. The specific gravity of the massive barite ranges from 3.73 to 4.36 , whereas that of the rosette and conglomeratic barite ranges from 3.64 to 3.97. The Stewart and Pfister (1960, p. 5) curve relating specific gravity to barite content suggests that the massive barite contains about 63 to 95 percent barite and that the rosette and conglomeratic barite contains about 58 to 75 percent barite. The chemical data in the table, however, suggest that the massive barite rock contains 86.3 to 93.9 percent barite and that the rosette and conglomeratic barite rocks contain 70.7 to 93.5 percent barite. Comparison of the chemical and specificgravity data indicate differences in porosity of the samples as well as a general negative correlation between silica content and specific gravity.

Chemical and X-ray-diffraction data summarized in the table indicate that silica as quartz is the principal impurity in the barite. The very small a mounts of strontium, lime, carbon dioxide, alumina, and total iron are insufficient to form enough of other minerals to show on the X-ray diffractograms. The strontium probably occurs in barite where it can substitute for barium in the crystal lattice. The lime probably occurs in combination with the carbon dioxide as very small amounts of calcite. Calcite was found only in the thin section and the X-ray diffractogram of sample DAB-8. All the lime in the analyses shown in the table cannot be accounted for as calcium carbonate because of insufficient carbon dioxide. The calcium, therefore, occurs in some other mineral, perhaps in limited substitution for barium or strontium in the barite. The iron probably occurs as minute particles of oxide or sulfide, although only a few grains of pyrite altering to reddish iron oxide were found in only one sample (DRS-25-67). The small amounts of alumina probably form minute amounts of clay. Discrete and definable clay minerals did not appear on the X-ray diffractograms.

As judged by the samples studied, the barite of the East Northumberland Canyon area compares favorably in chemical and physical characteristics with bedded barite mined for well-drilling mud and chemical uses in other areas, especially in Nevada and Arkansas (Brobst, 1958, p. 81, p. 92-97; Brobst, 1960, p. 60-63).

\section{POTENTIAL RESOURCES}

The economic potential of the barite deposits of the East Northumberland Canyon area cannot be fully evaluated without physical exploration such as drilling or excavation. Geologic relations as described in this report suggest that the potential resources are large and that the area constitutes an attractive exploration target. Although the deposits are in a thrust fault plate (Kay and Crawford, 1964, pl. 6) that puts limits on their extent, the surface exposures suggest that the deposits may extend 10,000 feet along strike and that they may have an average total thickness of 50 feet. Two measured sections and two estimated sections in the western part of the area of exposed bar ite on the south side of the canyon (fig. 2) show more than 50 feet average aggregate thickness of barite beds. The upper bed at the east end of the area on the south side of the canyon appears to be 30 to 40 feet thick, and three lower beds are each about 10 feet thick. In the southeastern part of the area of barite exposures on the north side of the canyon (fig. 2), the middle bed is estimated to be about 40 feet thick. and the upper and lower beds each estimated at least 10 feet thick. From this area, these thicknesses appear to continue both to the northwest and to the northeast. Despite the fact that the barite deposits appear to be in a thrust plate of the Pinecone Formation (Kay and Crawford, 1964, pl. 6), we believe that the plate is thick enough to suggest that the barite beds may extend at least 1,000 feet downdip. Dark-gray bedded barite also crops out in canyons as much as 4 miles north of the barite exposures shown in figure 2, as well as 5 miles to the northwest, but in these areas the barite beds seem to be thinner and more discontinuous than in the East Northumberland Canyon area, possibly because of tectonic deformation. 


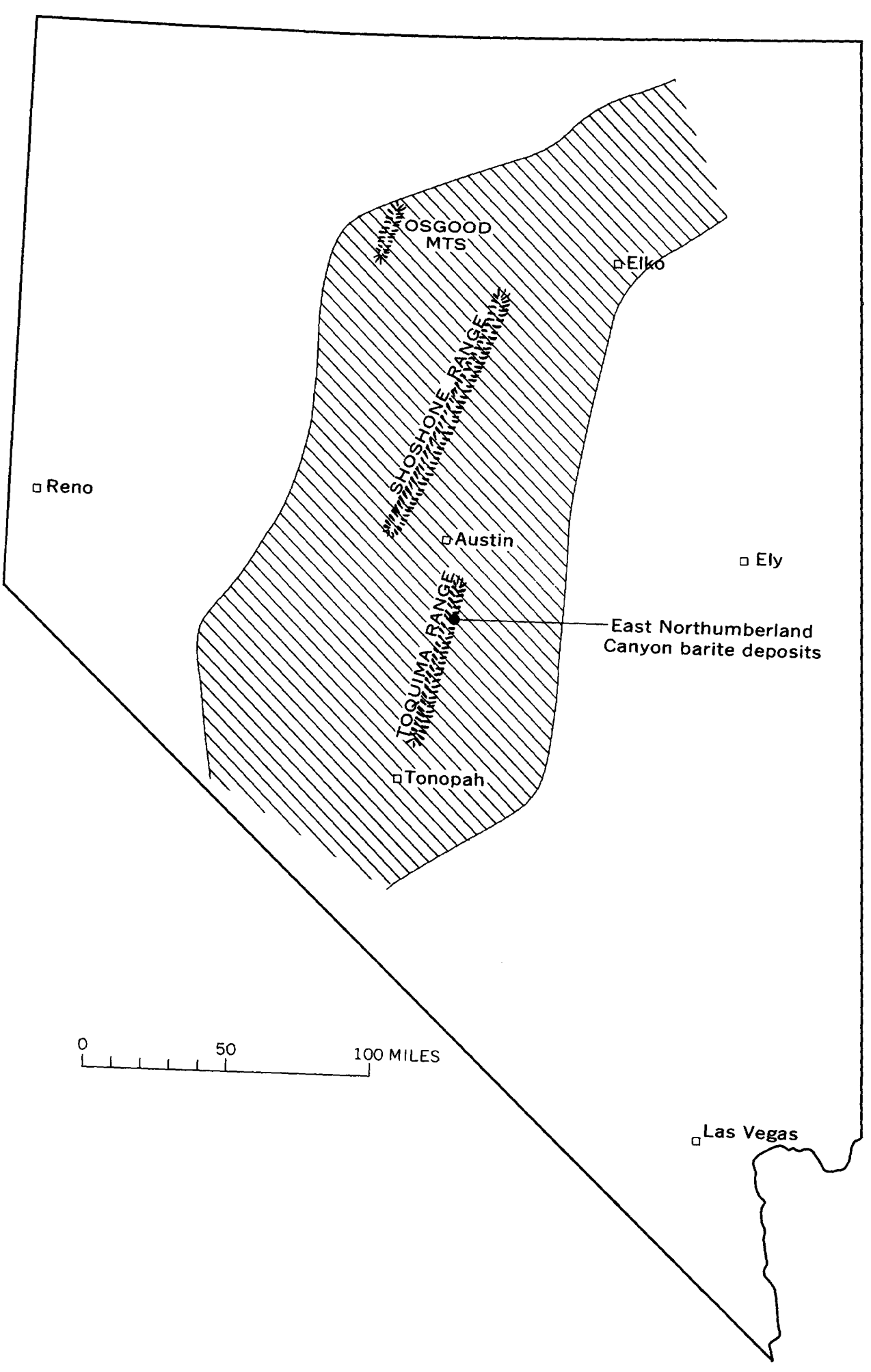
Figure 1.--Map of Nevada showing location of East Northumberland Canyon barite deposits and area
of central Nevada barite province (lined) based on Horton (1963). 


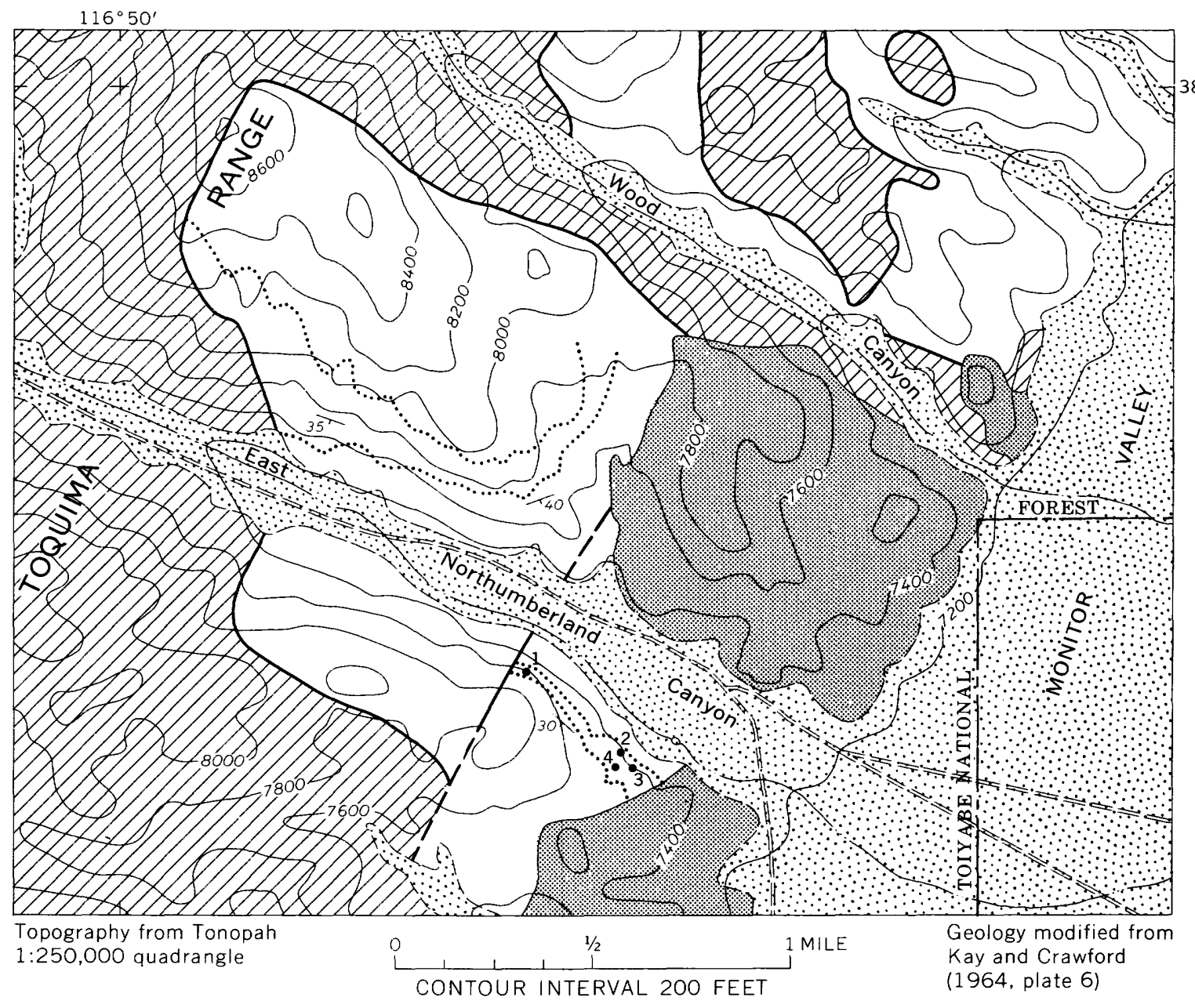

EXPLANATION

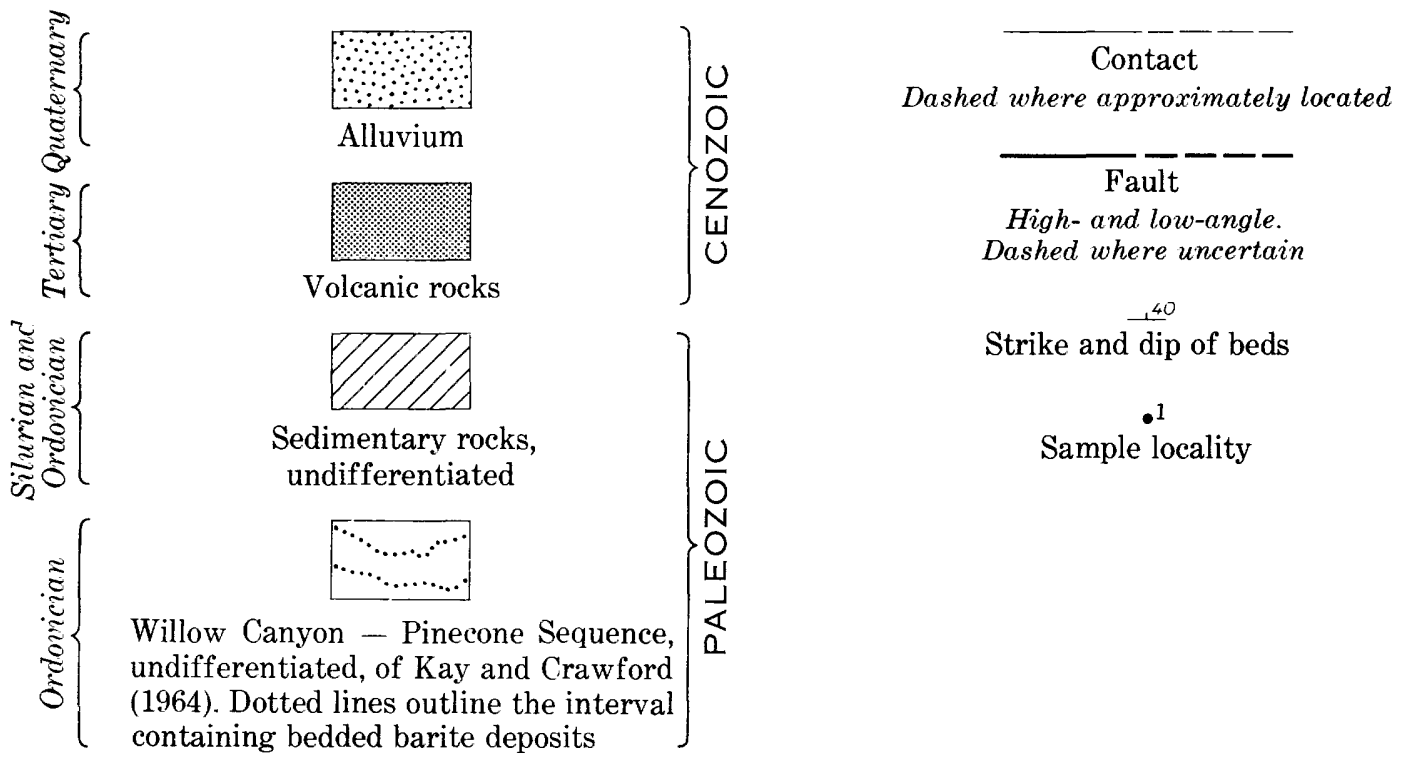

Figure 2.--Generalized gुeologic map of the East Northumberland Canyon area showing location of bedded-barite deposits. 


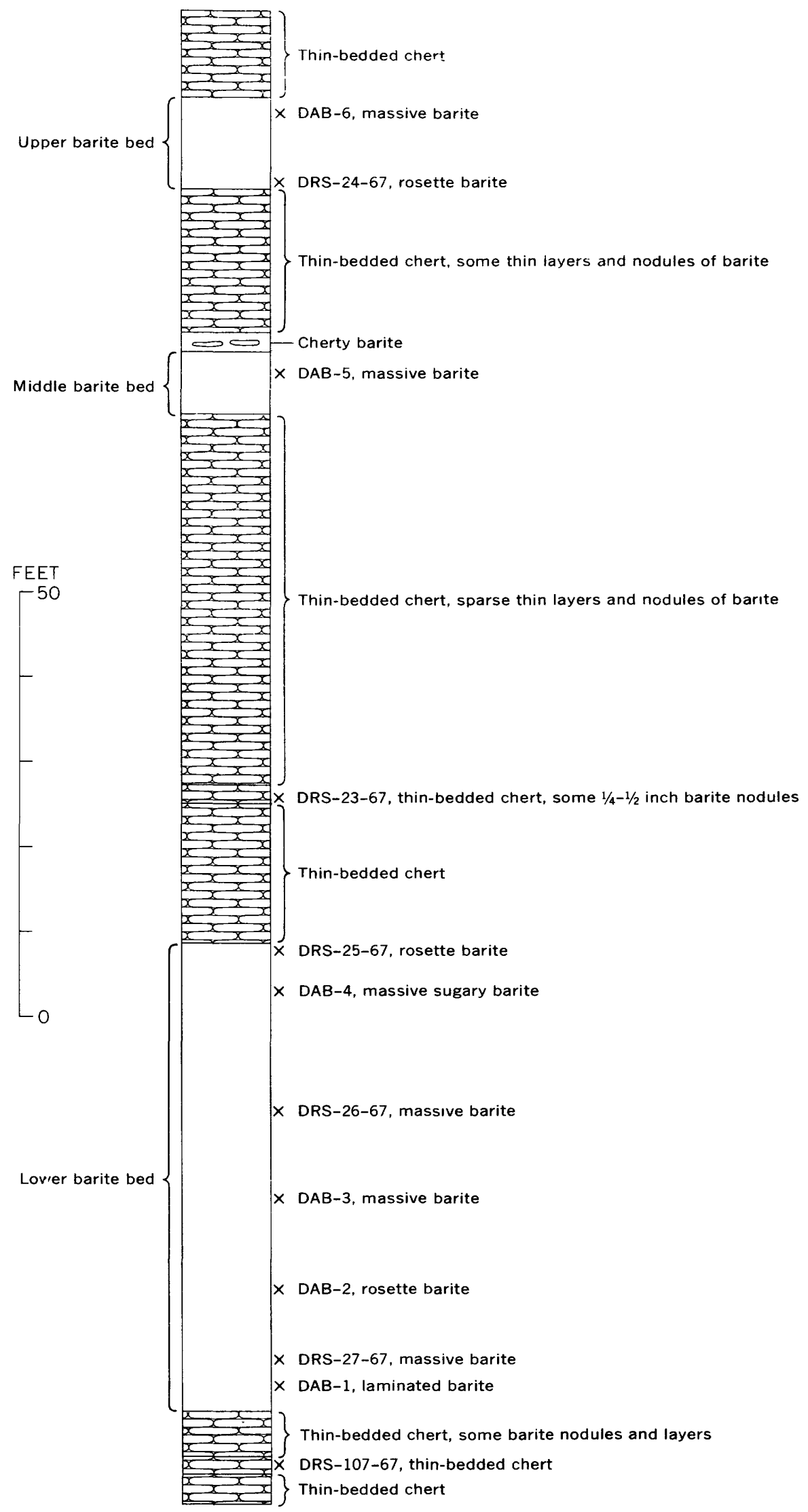

Figure 3.--Diagrammatic stratigraphic section of the barite-bearing zone, south side of East Northumberland Canyon, showing sample localities. Position of section shown on figure 2 as sample locality 1. 
Properties of barite and associated rocks fr

[Analysts, all uI' U.S. Geological Survey: J. D. Tucker for specific gravity; D. A. Brobst and J. D. Tucker for W. Mountjoy and O. M. Parker for $\mathrm{Fe}_{2} \mathrm{O}_{3}, \mathrm{Sr}$,

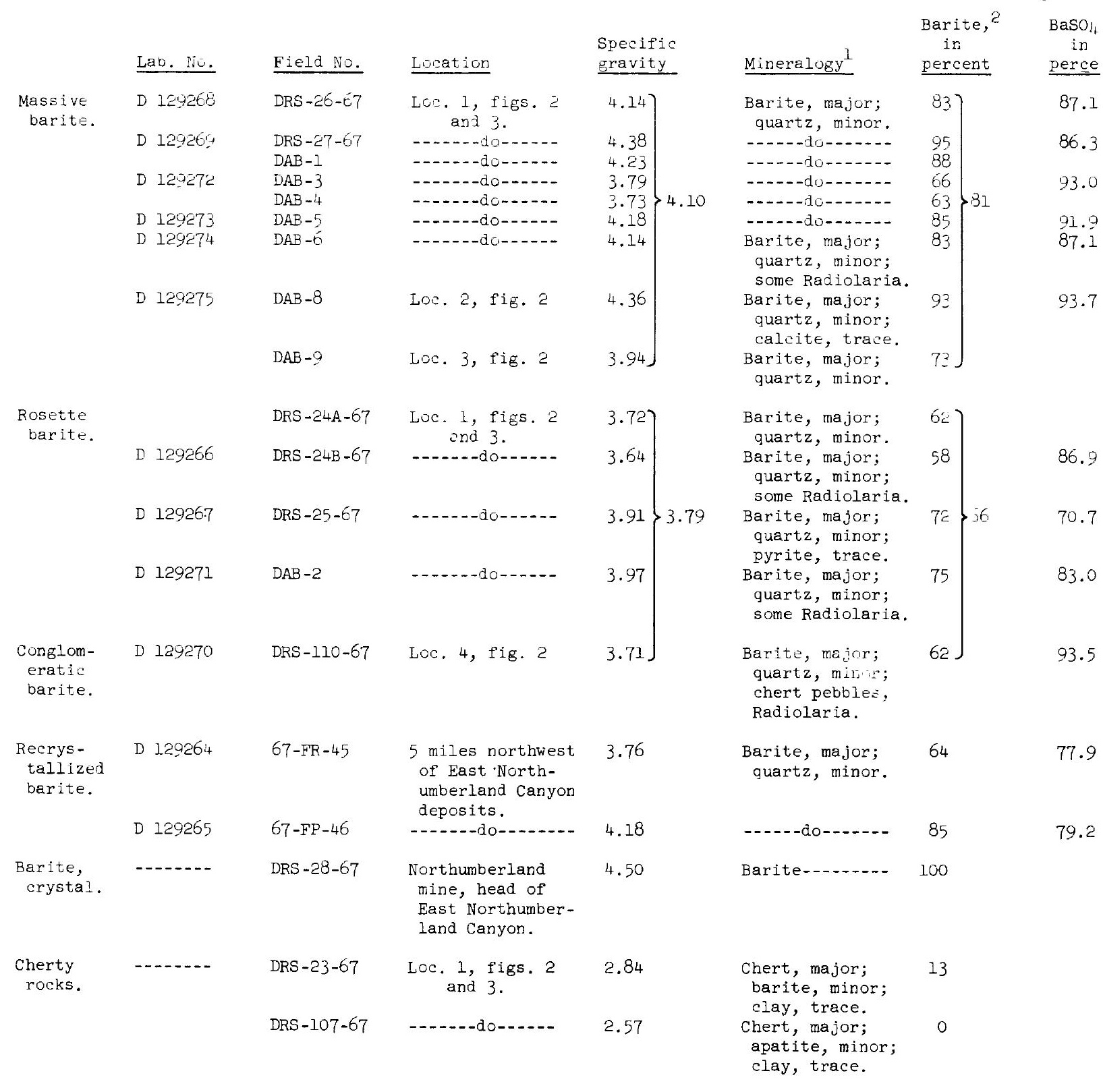

I/ From thin section and x-ray study.

E) Calculated from specific gravity, assuming only chert impurity with specific gravity 2.57 , and pure barite specific gravity 4.50 . 
the vicinity of East Northumberland Canyon

$\because$-ray diffractometry; V. E. Shaw for $\mathrm{Ba}$ and S; I. C. Frost and J. A. Thomas for total $\mathrm{C}$ and $\mathrm{CO}_{2}$; and $\mathrm{CaO}$; and $\mathrm{W}$. D. Goss for $\mathrm{SiO}_{2}$ and $\left.\mathrm{Al}_{2} \mathrm{O}_{3}\right]$

Chemical analyses, in percent

\begin{tabular}{|c|c|c|c|c|c|c|c|c|c|}
\hline$\underline{\mathrm{Ba}}$ & $\mathrm{SO}_{4}$ & $\begin{array}{l}\text { Total } \\
\mathrm{C} \\
\end{array}$ & $\begin{array}{l}\text { Total } \mathrm{Fe} \\
\text { as } \mathrm{Fe}_{2} \mathrm{O}_{3} \\
\end{array}$ & $\underline{S r}$ & $\mathrm{SiO}_{2}$ & $\underline{\mathrm{CaO}}$ & $\underline{\mathrm{CO}_{2}}$ & $\mathrm{Al}_{2} \mathrm{O}_{3}$ & Total 4 \\
\hline 51.3 & 38.81 & 3.48 & 0.17 & 0.11 & 9.2 & 0.59 & 0.06 & 0.011 & 100.7 \\
\hline 50.8 & 38.56 & .54 & .37 & .088 & 10.5 & .29 & .05 & .03 & 98.1 \\
\hline 54.7 & 40.37 & 1.66 & .04 & .046 & 5.5 & .22 & .07 & .05 & 100.5 \\
\hline $\begin{array}{l}54.1 \\
51.3\end{array}$ & $\begin{array}{l}39.88 \\
36.83\end{array}$ & $\begin{array}{l}3.08 \\
3.32\end{array}$ & $\begin{array}{l}.05 \\
.05\end{array}$ & $\begin{array}{l}.070 \\
.041\end{array}$ & $\begin{array}{l}6.3 \\
9.8\end{array}$ & $\begin{array}{l}.10 \\
.07\end{array}$ & $\begin{array}{l}.07 \\
.03\end{array}$ & $\begin{array}{l}.006 \\
.016\end{array}$ & $\begin{array}{l}101.5 \\
100.4\end{array}$ \\
\hline 55.3 & 40.70 & 4.12 & .06 & .15 & 2.4 & 1.28 & 1.72 & .006 & 101.9 \\
\hline 51.2 & 39.30 & .43 & .06 & .094 & 11.0 & .11 & .04 & .006 & 98.6 \\
\hline 41.6 & 30.99 & .51 & .34 & .020 & 25.8 & 1.40 & .03 & .016 & 98.8 \\
\hline 48.8 & 36.69 & 1.11 & .08 & .058 & 15.8 & .24 & $<.01$ & .009 & 100.3 \\
\hline 55.1 & 39.55 & 1.77 & .06 & .073 & 3.8 & .21 & .05 & .007 & 99.4 \\
\hline 45.8 & 33.71 & .10 & .05 & .014 & 19.9 & .34 & .14 & .007 & 98.3 \\
\hline 46.6 & 37.58 & .12 & .19 & .042 & 19.3 & .33 & $<.01$ & .008 & 99.2 \\
\hline
\end{tabular}

3/ Calculated from chemical analyses for $\mathrm{Ba}$.

4/ Total is sum of $\mathrm{BaSO}_{4}$ calculated from $\mathrm{Ba}$, total $\mathrm{C}$, total $\mathrm{Fe}$ as $\mathrm{Fe}_{2} \mathrm{O}_{3}, \mathrm{Sr}$, $\mathrm{SiO}_{2}, \mathrm{CaO}$, and $\mathrm{Al}_{2} \mathrm{O}_{3}$ and is given only to show approximate chemical

balance. 
The demonstrated reserves of barite ore in the United States exploitable under current technological and economic conditions were placed by Brobst (1958, p. 120) at about 285 million tons of ore containing 46 million tons of barite. If the barite in the East Northumberland Canyon area should prove upon exploration to be of the extent and quality that geologic indications suggest, it would add appreciably to domestic reserves.

Through the last decade, the domestic barite industry has been producing at the rate of about 1 million tons of barite a year. About 600,000 tons, with a value of about $\$ 10$ million, is imported annually. About 90 percent of the consumption is used in oil-well drilling mud, and 10 percent is used in the preparation of barium chemicals and in many other industrial uses. The East Northumberland Canyon barite appears to be of a quality suitable for either the chemical or the drillingmud trade.

\section{GEOLOGICAL INTERPRETATIONS}

The origin of bedded barite deposits is not well understood, but textural, structural, and paleontological features of the barite beds in EastNorthumberland Canyon suggest that the barite was deposited early in the history of the rocks. The radiolarian nuclei from which blades of barite radiate to form rosettes implies first that space for crystal growth was available and, hence, that the beds were not compacted and second implies that replacement was not instrumental in formation of the barite crystals. The intraformational barite conglomerate with its detrital chert fragments and subrounded to angular fragments of barite in a matrix of fine-grained barite implies erosion and redeposition of previously deposited barite in an active marine environment during the time of the deposition of the Pinecone Formation. The streaks and patches of organic matter interstitial to the barite appear to be of primary origin. Their presence suggess that the rocks have not been subjected either to particularly hot or to particularly alkaline or acidic solutions. Submarine springs could have been a source of barium and silica in a marine environment. The barium sulfate and silica might have been precipitated either by marine organisms or by direct chemical reactions.

The occurrence of barite- and silica-rich facies in Ordovician rocks in the Toquima Range, as well as in the southern Shoshone Range and the Osgood Mountains, Nev. (fig. 1) suggests that these rocks constitute a significant sedimentary facies in the eugeosynclinal Paleozoic rocks of the Antler orogenic belt described by Roberts and others (1958) in the Great Basin. An examination of these Paleozoic rocks may lead to further discoveries of bedded barite deposits. The tectonic thicknening and thinning of the baritic rocks, and their tectonic transport, may also contribute to the understanding of structural deformation in the region.

\section{REFERENCES CITED}

Brobst, D. A., 1958, Barite resources of the United States: U.S. Geol. Survey Bull. 1072-B, p. 67-130. 1960, Barium minerals, chap. 3, p. 55-64, in Industrial minerals and rocks, J. L. Gillson, ed.: Am. Inst. Mining Metall. Engineers, New York. Horton, R. C., 1963, An inventory of barite occurrences in Nevada: Nevada Bureau of Mines, Rept. 4, 18 p.

Kay, Marshall, and Crawford, J. P., 1964, Paleozoic facies from the miogeosynclinal to eugeosynclinal belt in thrust slices, central Nevada: Geol. Soc. America Buil., v. 75, p. 425-454.

Roberts, R. J., Hotz, P. E., Gilluly, James, and Ferguson, H. G., 1958, Paleozoic rocks of northcentral Nevada: Am. Assoc. Petroleum Geologists Bull., v. 42, no. 12, p. $2813-2857$.

Stewart, L. A., and Pfister, A. J., 1960, Barite deposits of Arizona: U.S. Bur. Mines, Rept. Inv. 5651, 89 p. 

